\title{
Influence of Fertility Level on the Protein Content and Agronomic Characters of Pigeonpeas in an Oxisol
}

\author{
R. Pietri, R. Abrams, and F. J.Juliá ${ }^{1}$
}

\section{INTRODUCTION}

Pigeonpea (Cajanus cajan) is the most important legume crop grown in Puerto Rico for human consumption. The total grain yield during the past 5 years has been about $4,545,454$ lilograms $(5,000$ tons or 100,000 hundredweights), with a mean yield per ha. (hectare) of approximately $900 \mathrm{~kg}$. (800 lbs./A). The 1970 farm value of the crop has been estimated at over $\$ 3$ million, an increase of about 50 percent over the previous year. Approximately 85 percent of the crop is processed and canned by various factories in the Island. Because of the potentialities of this legume crop to the economy of Puerto Rico, intensive research has been conducted over the past 10 years in breeding, cultural practices, pest control and processing to improve the yield and quality of pigeonpea.

The available $N, P$, and $K$ in most Oxisols of Puerto Rico is less than the requirements for optimum production of most crops. A number of fertility trials with different levels of $N, P$, and $K$ fertilizers did not result in increased yields of pigeonpeas. Landrau and Samuels ${ }^{2}$ reported no response in yield of pigeonpeas to different levels of $\mathrm{N}, \mathrm{P}$, and $\mathrm{K}$ in experiments conducted in a Yauco clay at Peñuelas and in a Coto clay at Isabela. Similar results were reported by Pérez-López. ${ }^{3}$

It was shown recently in Hawaii, ${ }^{4}$ that application of calcium silicate to strongly weathered sugarcane soils significuntly increased production of sugar per ha. Based on this data, it was considered that application of calcium silicate might furnish additional needed information concerning soil nutrition and its influence on the protein content and agronomic characters of pigeonpeas.

The present report is based on experiments designed to evaluate further the response of pigeonpeas to different rates of $N, P$, and $K$ with and without $\mathrm{Ca}, \mathrm{Mg}$, and to two levels of calcium silicate.

1 Professor of Soils, College of Agricultural Seiences, and Plant Breeder and Assist ant Agronomist, respectively, Isabela Substation, Agricultural Experiment Station, Mayagüez Campus, University of Puerto Rico, Río Piedras, P.R.

${ }^{2}$ Landrau, P. and Samuels, (i., The effects of fertilizer applications on yields of pigeonpeas, $J$. Agr. Univ. P.R. 48 (1): 69-72, 1959.

3 Personal communication.

+ Ilawaii Agricultural lexperiment Station, University of Hawaii, Biemal Report $196 i j-48$, .Ju1e 1970. 


\section{MATERIALS AND METHODS}

All experiments were conducted in $\mathbf{1 9 7 0}$ on a Coto clay (Typic Haplorthox, clayey, Kaolinitic, isohyperthermic) at the Isabela Agricultural Experiment Substation. After the initial preparation of the land, soil samples were taken for $\mathrm{pH}$ determination and nematode counts.

The pigeonpea cultivar Kaki was planted in hills $60 \mathrm{~cm}$. (2 feet) apart within the row and $120 \mathrm{~cm}$. (4 feet) between rows. Prometryne was applied as a pre-emergent herbicide at the rate of $3.33 \mathrm{~kg} . / \mathrm{ha} .(3 \mathrm{lbs} . / \mathrm{A})$ and Paraquat was applied as a post-emergent at the rate of $1.18 \mathrm{liter} / \mathrm{ha}$. (16 oz./A) when the plants were about $45 \mathrm{~cm}$. (18 inches) tall.

Nine fertilizer treatments, including an unfertilized control, were arranged in a randomized-block design with four replications. A granulated nematocide (Mocap) was applied in the rows at, the rate of $45 \mathrm{~kg}$./ha. (40 lbs./A) to the entire experimental field at the time of fertilizer application. The $\mathrm{pH}$ was adjusted with calcium carbonate, except for the unfertilized control and the calcium silicate treatments, to a 75 -percent-base exchange capacity saturation. The calcium silicate treatments were incorporated in the soil with a rotavator. Each plot consisted of four rows, each $6 \mathrm{~m}$. long. The two middle rows were harvested for green pod yield. Data was tabulated for agronomic characters and chemical determination of protein from each replicate.

Data concerning the following characters was tabulated: green pod yield, number of days from planting to flowering, plant height, seed weight, and percentage of protein in the dry seed. Date of flowering was recorded when 50 percent of the plants in the plot were in bloom. Height was the length of the plant from ground level to the top of the stem at harvesting. Seed weight was recorded in g. per 100 green seeds. Protein determinations were made on representative portions of seeds from single plots. Protein content was determined by multiplying the percentage of nitrogen by 6.25 and is reported on a moisture-free basis as percentage of crude protein.

\section{RESULTS AND DISCUSSION}

The data showing the effect of different levels of $N, P$, and $K$ with and without $\mathrm{Ca}, \mathrm{Mg}$ and calcium silicate on yield, plant height, date of flowering, seed weight and protein content of pigeonpea cultivar Kaki, are given in table 1. These are very similar to those obtained by Landrau and Samuels in regard to yield of green pods, i.e., that the yields of the non-fertilizer treatments were not significantly different from those of the fertilizer treatments. It was thought when plamning the experiment that differences in yield might result from adjusting the $\mathrm{pH}$ with calcium carbonate to a 75-percent-base exchange saturation, and by making additional treatments 
with $\mathrm{Mg}$ and calcium silicate. More mineral elements were included in these experiments than in those conducted by Landrau and Samuels, and data was recorded concerning more plant characters. No significant difference resulted between the several fertilizer treatments and the control for any of the above plant characters or mineral elements.

The height of the plants was recorded monthly until harvesting time to detect any difference in vigor during the early stages of development. When the various treatments were compared, there was no significant difference in the height of the plants during any of the months recorded.

Protein percentage was about the same for all treatments. Requirements of $\mathrm{P}, \mathrm{K}, \mathrm{Ca}$ and $\mathrm{Mg}$ for all the characters studied apparently is not too

T.ABLE: 1.-The effect of different levels of $N, P$, and $K$ with and without Ca, Mg and ralcium silicale on flowering date, plant height, secd weight, green pod yield and prolein ronlent of Kaki Pigconpea

\begin{tabular}{|c|c|c|c|c|c|c|c|c|c|c|}
\hline \multicolumn{6}{|c|}{ Fertilizer } & \multirow{2}{*}{$\begin{array}{l}\text { Plant } \\
\text { height }\end{array}$} & \multirow{2}{*}{$\begin{array}{l}\text { Planting to } \\
\text { flowering } \\
\text { date }\end{array}$} & \multirow{2}{*}{ Yield } & \multirow{2}{*}{$\begin{array}{c}\text { Weight } \\
\text { per 100 } \\
\text { secds }\end{array}$} & \multirow{2}{*}{ Protein } \\
\hline $\mathrm{N}$ & $P$ & $\mathbf{K}$ & $\mathrm{Mg}_{\mathrm{g}}$ & $\mathrm{Ca}$ & $\mathrm{Si}$ & & & & & \\
\hline Lbs. & $L b s$. & Lbs. & Lbs. & Lbs. & Lbs. & $\mathrm{Cm}$. & Days & Kg./ha. & Grams & Percent \\
\hline 0 & 0 & 0 & 0 & 0 & 0 & 175.3 & 158 & $6,053.4$ & 39.6 & 21.3 \\
\hline 0 & 150 & 150 & 50 & 75 & 0 & 175.3 & 157 & $5,829.2$ & 35.8 & 20.6 \\
\hline 100 & 150 & 150 & 50 & 75 & 0 & 172.7 & 158 & $5,605.0$ & 38.8 & 21.4 \\
\hline 0 & 150 & 150 & 50 & 0 & 4,000 & 172.7 & 157 & $5,605.0$ & 37.9 & 21.8 \\
\hline 0 & 150 & 150 & 50 & 0 & 8,000 & 175.3 & 161 & $6,053.4$ & 38.2 & 21.2 \\
\hline 0 & 150 & 150 & 100 & 75 & 0 & 175.3 & 156 & $5,717.1$ & 37.8 & 21.1 \\
\hline 0 & 0 & 150 & 50 & 75 & 0 & 172.7 & 158 & $5,605.0$ & 36.9 & 21.5 \\
\hline 0 & 150 & 0 & 50 & 85 & 0 & 180.0 & 156 & $5,829.2$ & 39.7 & 21.1 \\
\hline 0 & 150 & 150 & 0 & 75 & 0 & 170.2 & 162 & $5,492.9$ & 36.5 & 21.0 \\
\hline
\end{tabular}

high. This Oxisol, although low in some of these elements, appears to contain available amounts sufficient to meet the requirements of pigeonpeas. Being a legume, pigeonpea apparently can fix enough nitrogen to develop normally in unfertilized plots without adverse changes in vigor, productivity or chemical composition of the seed.

\section{SUMMARY}

The effect of different levels of $\mathrm{N}, \mathrm{P}$, and $\mathrm{K}$ with and without $\mathrm{Ca}, \mathrm{Mg}$ and two levels of calcium silicate, was studied on Kali pigeonpea in an Oxisol at the Isabela Experiment Substation. The study confirmed previous results showing that fertilizer treatments have no effect on green pod yield, date of flowering, plant height, seed weight or protein content of the dry seed. 


\section{RESUMEN}

Se estudió el efecto de diferentes niveles de $\mathrm{N}, \mathrm{P}$ y $\mathrm{K}$ con y $\sin \mathrm{Ca}, \mathrm{Mg}$ y dos niveles de silicato de calcio en el gandur de la variedad Kaki. El estudio se realizó en un suelo Oxisol en la Subestación Experimental de Isabela. Los resultados obtenidos confirmaron estudios anteriores en los que se probó que el abonamiento no afecta la producción de vainas verdes, fecha de floración, altura de la planta, peso del grano verde y contenido de proteína del grano seco. 